Article

\title{
Collapse Mechanisms of Nascent and Aged Sea Spray Aerosol Proxy Films
}

\author{
Kimberly A. Carter-Fenk ${ }^{(D)}$ and Heather C. Allen $(\mathbb{D} *$ \\ Department of Chemistry \& Biochemistry, The Ohio State University, 100 W. 18th Ave., Columbus, \\ OH 43210, USA; carter.1118@osu.edu \\ * Correspondence: allen@chemistry.ohio-state.edu; Tel.: +1-614-292-4707
}

Received: 14 November 2018; Accepted: 14 December 2018; Published: 18 December 2018

\begin{abstract}
Sea spray aerosol (SSA) is highly enriched in marine-derived organic compounds during seasons of high biological productivity, and saturated fatty acids comprise one of the most abundant classes of molecules. Fatty acids and other organic compounds form a film on SSA surfaces, and SSA particle surface-area-to-volume ratios are altered during aging in the marine boundary layer (MBL). To understand SSA surface organization and its role during dynamic atmospheric conditions, an SSA proxy fatty acid film and its individual components stearic acid (SA), palmitic acid (PA), and myristic acid (MA) are studied separately using surface pressure-area $(\Pi-A)$ isotherms and Brewster angle microscopy (BAM). The films were spread on an aqueous $\mathrm{NaCl}$ subphase at $\mathrm{pH} 8.2,5.6$, and 2.0 to mimic nascent to aged SSA aqueous core composition in the MBL, respectively. We show that the individual fatty acid behavior differs from that of the SSA proxy film, and at nascent SSA pH the mixture yields a monolayer with intermediate rigidity that folds upon film compression to the collapse state. Acidification causes the SSA proxy film to become more rigid and form 3D nuclei. Our results reveal film morphology alterations, which are related to SSA reflectivity, throughout various stages of SSA aging and provide a better understanding of SSA impacts on climate.
\end{abstract}

Keywords: sea spray; aerosol; isotherm; Brewster angle microscopy; monolayer; air-water interface; collapse

\section{Introduction}

Sea spray aerosol (SSA), generated from breaking waves at the ocean surface, constitutes one of the largest sources of aerosol emissions on the planet [1]. The greatest degree of uncertainty in climate models is the representation of aerosols, of which the magnitude of radiative forcing by natural aerosol emissions is poorly constrained [2]. Aerosols directly affect climate by absorbing and scattering solar radiation, and aerosols indirectly influence the global radiative budget by acting as cloud condensation nuclei (CCN) and ice nuclei (IN) in the atmosphere [3]. The ability of SSA to nucleate ice [4-12], seed clouds [13-20], and participate in atmospheric chemical reactions [21-24] is dependent upon the size, chemical composition, and phase state of SSA particles [25-29]. Additionally, given that a large fraction of aerosols have high surface-area-to-volume ratios, molecular organization at the air-water interface of SSA is especially relevant in inducing these atmospheric reactions and nucleation processes [30-37]. Hence, developing and characterizing the interfacial composition, organization, and reactivity of SSA proxy systems is crucial for improved predictions of aerosol impacts on climate [38-40].

The chemical diversity of nascent SSA is caused in part by the production mechanism and the biological productivity of the source seawater [1,41-44]. Organic matter that is transferred to SSA is derived from marine biota, primarily from phytoplankton blooms [45-53]. Surface active material such as lipids, proteins, and polysaccharides [37,54-58] partition to the air-sea interface where 
they can be encapsulated into bubbles and burst to form SSA particles between $10 \mathrm{~nm}$ and $5 \mu \mathrm{m}$ in diameter $[1,49,59]$. Supermicron SSA composition more closely resembles that of upper surface seawater, so larger SSA particles contain more oxygenated compounds and have a higher fraction of soluble organic material, including short- to medium-chain fatty acids. Submicron SSA composition tends to be enriched in aliphatic compounds, such as long-chain fatty acids $[49,54,57,58,60,61]$. In both supermicron and submicron SSA, fatty acids of moderate aliphaticity are throught to form films on SSA surfaces $[37,54,62,63]$. The 2D organization of these films modulate gas and water uptake into the aqueous bulk of the particle $[22,23,36,52,64,65]$. As a result, experiments involving ocean-relevant SSA film proxies are important for better predictions of aerosol reactivity and nucleation capability in climate models.

During phytoplankton blooms, organic enrichment within SSA is increased such that the competition for space at the SSA surface is high due to the surface activity of the marine-derived organic compounds. Fatty acids, which represent some of the most surface active components in SSA, condense to accommodate for the high surface density of organic molecules at the interface. The ability of the film (i.e., monolayer) to condense and resist transformation from the 2D film into 3D structures is dependent upon the film rigidity which is modulated by lateral interactions between the fatty acid alkyl chains and by interactions between the underlying aqueous core and carboxylic acid head groups [66-70]. Shorter chain fatty acids in nascent SSA are expected to be more soluble [71,72] given that the particles have an initial seawater $\mathrm{pH}$ of $\sim 8.2$. As a result, the longer fatty acids will dominate the lateral interactions in the SSA film, making the film more rigid due to the greater sum of dispersion interactions $[66,73,74]$. Carboxylic acid head groups of long chain fatty acids $\left(>C_{14}\right)$ are only partially deprotonated at high $\mathrm{pH}$ due to their relatively high surface $\mathrm{pK}_{a}$ values [75,76]. However, cation-head group interactions slightly moderate the $\mathrm{pK}_{a}$ increase associated with increasing alkyl chain length [76]. As SSA ages in the marine boundary layer (MBL), the particles interact with trace gases that lower the $\mathrm{pH}$ of the particle aqueous core. Consequently, shorter fatty acids are less soluble and more surface active, so the SSA film is fluidized [77-80]. SSA film behavior can be represented by 2D Langmuir isotherms in which a fatty acid monolayer is compressed beginning at low surface coverage, and the monolayer surface pressure is measured with decreasing surface area [64]. Film rigidity dictates the maximum monolayer surface pressure $\left(\Pi_{\mathcal{c}}\right)$ attainable before collapse into 3D structures [81-85], thereby changing the phase state of the film.

SSA proxy film collapse mechanisms are examined on aqueous $\mathrm{NaCl}$ subphases to elucidate changes in film morphology with particle aging in the MBL. A fatty acid mixture composed of myristic acid $\left(\mathrm{C}_{14}, \mathrm{MA}\right)$, palmitic acid $\left(\mathrm{C}_{16}, \mathrm{PA}\right)$, and stearic acid $\left(\mathrm{C}_{18}, \mathrm{SA}\right)$ at the molar ratio of $3 \mathrm{SA}: 4$ PA:2 MA is studied to mimic the dominant surfactant composition in fine SSA (diameter $\leq 2.5 \mu \mathrm{m}$ ). PA and SA constitute about two-thirds of the saturated fatty acids in fine SSA, and MA is the third most abundant species [54]. The aqueous core of nascent SSA is modeled by a $0.4 \mathrm{M} \mathrm{NaCl}$ subphase at $\mathrm{pH}$ 8.2 [86], and aged SSA is modeled with the aqueous $\mathrm{NaCl}$ subphase adjusted to $\mathrm{pH} 5.6$ and 2.0 [87]. Surface pressure-area $(\Pi-A)$ isotherms are conducted to measure the SSA proxy film phase behavior, and Brewster angle microscopy (BAM) images of the SSA proxy film collapse are taken at each $\mathrm{pH}$. Differences in monolayer phase behavior and collapse between the SSA proxy film and its individual components are observed, highlighting the importance of using more complex model systems to elucidate atmospherically-relevant SSA film behavior. Additionally, changes in SSA film collapse mechanisms as a function of $\mathrm{pH}$ are measured. From our results, we expect that subphase composition and $\mathrm{pH}$ will play a major role in modulating SSA film morphology which will then impact particle trace gas uptake and nucleation ability in the MBL. 


\section{Materials and Methods}

\subsection{Materials}

Myristic acid $\left(\mathrm{C}_{14} \mathrm{H}_{28} \mathrm{O}_{2}, \mathrm{MA}, \geq 99 \%\right.$, Sigma-Aldrich, Saint Louis, MO, USA), palmitic acid $\left(\mathrm{C}_{16} \mathrm{H}_{32} \mathrm{O}_{2}, \mathrm{PA}, \geq 99 \%\right.$, Sigma-Aldrich), and stearic acid $\left(\mathrm{C}_{18} \mathrm{H}_{36} \mathrm{O}_{2}, \mathrm{SA}, \geq 99 \%\right.$, Sigma-Aldrich) were used without further purification. Each fatty acid was dissolved in chloroform (HPLC Grade, Fisher Scientific, Fair Lawn, NJ, USA) at a concentration of $3 \mathrm{mM}$. Aliquots of the individual fatty acid solutions were mixed according to the molar ratio of 2 MA:4 PA:3 SA to produce the mixed lipid stock solution in duplicate. $\mathrm{NaCl}$ (Sodium chloride, 99+\%, ACS reagent, Acrōs Organics, Fair Lawn, NJ, USA) was baked at $650{ }^{\circ} \mathrm{C}$ in a furnace (Fisher Scientific Isotemp ${ }^{\circledR}$ Muffle Furnace, Dubuque, IA, USA) for at least $10 \mathrm{~h}$ to remove residual organics [88]. The salt was dissolved in ultrapure water with a resistivity of $18.2 \mathrm{M} \Omega \cdot \mathrm{cm}$ (Milli-Q Advantage A10, EMD Millipore, Billerica, MA, USA) and with a $\mathrm{pH}$ of 5.6 because of acidification by atmospheric $\mathrm{CO}_{2}$. Acidic subphases were prepared at $\mathrm{pH} 2.0$ via the addition of $\mathrm{HCl}$ (Hydrochloric Acid, TraceMetal ${ }^{\mathrm{TM}}$ Grade, Fisher Scientific). Only the $0.4 \mathrm{M} \mathrm{NaCl}$ solution could be adjusted to $\mathrm{pH} 8.2$ via NaOH (Sodium Hydroxide Pellets, Mallinckrodt Analytical Reagent, Paris, KY, USA) addition. Water at $\mathrm{pH} 8.2$ acidified rapidly over the course of an experiment, but the $0.4 \mathrm{M} \mathrm{NaCl}$ solution acidified more slowly. Therefore, the solution was initially prepared at $\mathrm{pH} 8.5$ so that the $\mathrm{pH}$ would drop to $8.2 \pm 0.1$ while data was recorded.

\subsection{Surface Pressure-Area Isotherms}

Surface pressure-area $(\Pi-A)$ isotherms were performed in triplicate on a Teflon Langmuir Mini-Micro trough (KSV NIMA, Biolin Scientific, Espoo, Finland, area $144.5 \mathrm{~cm}^{2}$ ) and Delrin barriers (KSV NIMA). Both the trough and barriers were thoroughly cleaned with reagent alcohol (Histological Grade, Fisher Scientific, Fair Lawn, NJ, USA) and ultrapure water. Surface pressure was measured by the Wilhelmy plate method using a filter paper plate (Ashless Grade 41, Whatman, GE Healthcare, Chicago, IL, USA), and the paper plate was fully wetted prior to running an isotherm. The barriers were swept across the surface at the maximum compression speed $(270 \mathrm{~mm} / \mathrm{min} /$ barrier $)$ to check for surface cleanliness, indicated by a surface pressure value $\leq 0.20 \mathrm{mN} / \mathrm{m}$. A microsyringe $(50 \mu \mathrm{L}$, Hamilton, Reno, NV, USA) was used to spread the lipid solution dropwise onto the aqueous subphase. Ten minutes were allowed for solvent evaporation, and then the monolayer was symmetrically compressed at a rate of $10 \mathrm{~mm} /$ minute $(5 \mathrm{~mm} / \mathrm{min} /$ barrier $)$. All $\Pi-A$ isotherms were conducted at $21.8 \pm 0.5^{\circ} \mathrm{C}$ and a relative humidity of $37 \pm 6 \%$. (Relative humidity is not expected to change the monolayer collapse mechanism.)

\subsection{Brewster Angle Microscopy (BAM)}

Brewster angle microscope images were collected simultaneously with $\Pi-A$ isotherms using a custom-built BAM setup similar to that described previously in the literature $[89,90]$. Plane-polarized light at $543 \mathrm{~nm}$ was produced by a $1.5 \mathrm{~mW}$ He-Ne laser source (Meredith Instruments, Peoria, AZ, USA) with linear 500:1 polarization, and the p-polarized light was further purified by a Glan-laser calcite polarizer (Thorlabs, Newton, NJ, USA). The BAM was built on a goniometer and positioned along the Brewster angle of the air-water interface at 53.1 ${ }^{\circ}$. Reflected light was then sent through a 10X infinity-corrected super long working distance objective lens (CFI60 TU Plan EPI, Nikon Instruments, Melville, NY, USA). The magnified image was further collimated and focused using a tube lens (MXA22018, Nikon Instruments; focal length $200 \mathrm{~mm}$ ) before being sent to the back-illuminated EM-CCD camera (iXon DV887-BV, Andor Technology USA, Concord, MA, USA; $512 \times 512$ active pixels, $16 \mu \mathrm{m} \times 16 \mu \mathrm{m}$ pixel size). The BAM images were processed using ImageJ software (version 1.52a, National Institutes of Health, Bethesda, MD, USA) [91] and cropped from their original size of $8.2 \times 8.2 \mathrm{~mm}$ to show only the region of highest resolution. 


\section{Results and Discussion}

\subsection{Nascent SSA Proxy Film Phase Behavior}

Although cations tend to be enriched in SSA relative to their concentrations in seawater, $\mathrm{Na}^{+}$is not enriched [57,58]. Consequently, $0.4 \mathrm{M} \mathrm{NaCl}$ was added to the $\Pi-A$ isotherm subphase to model the $\mathrm{Na}^{+}$ion concentration in seawater in order to understand how the aqueous core of SSA impacts lipid organization in its organic coating [86,92]. Additionally, the $\mathrm{pH}$ of the subphase was adjusted to mimic that of seawater at $\mathrm{pH}$ 8.2. $\Pi-A$ isotherms of the SSA proxy film (2 MA: 4 PA:3 SA) and its individual fatty acid components on $0.4 \mathrm{M} \mathrm{NaCl}$ at $\mathrm{pH} 8.2$ are shown in Figure 1 [86]. A BAM image of the SSA proxy monolayer collapse is also displayed as an inset in Figure 1a. Fatty acid mixtures containing different chain lengths have been previously shown to be fully miscible [93], so the the SSA proxy film should be entirely homogeneous. However, isotherms of the individual fatty acids were measured to evaluate how their phase behavior differs from the SSA proxy film mixture. If differences are observed in phase behavior, this suggests that individual fatty acid monolayers do not fully capture MBL SSA surface organization and dynamics.

SSA Proxy, $0.4 \mathrm{M} \mathrm{NaCl}$ at $\mathrm{pH} 8.2$
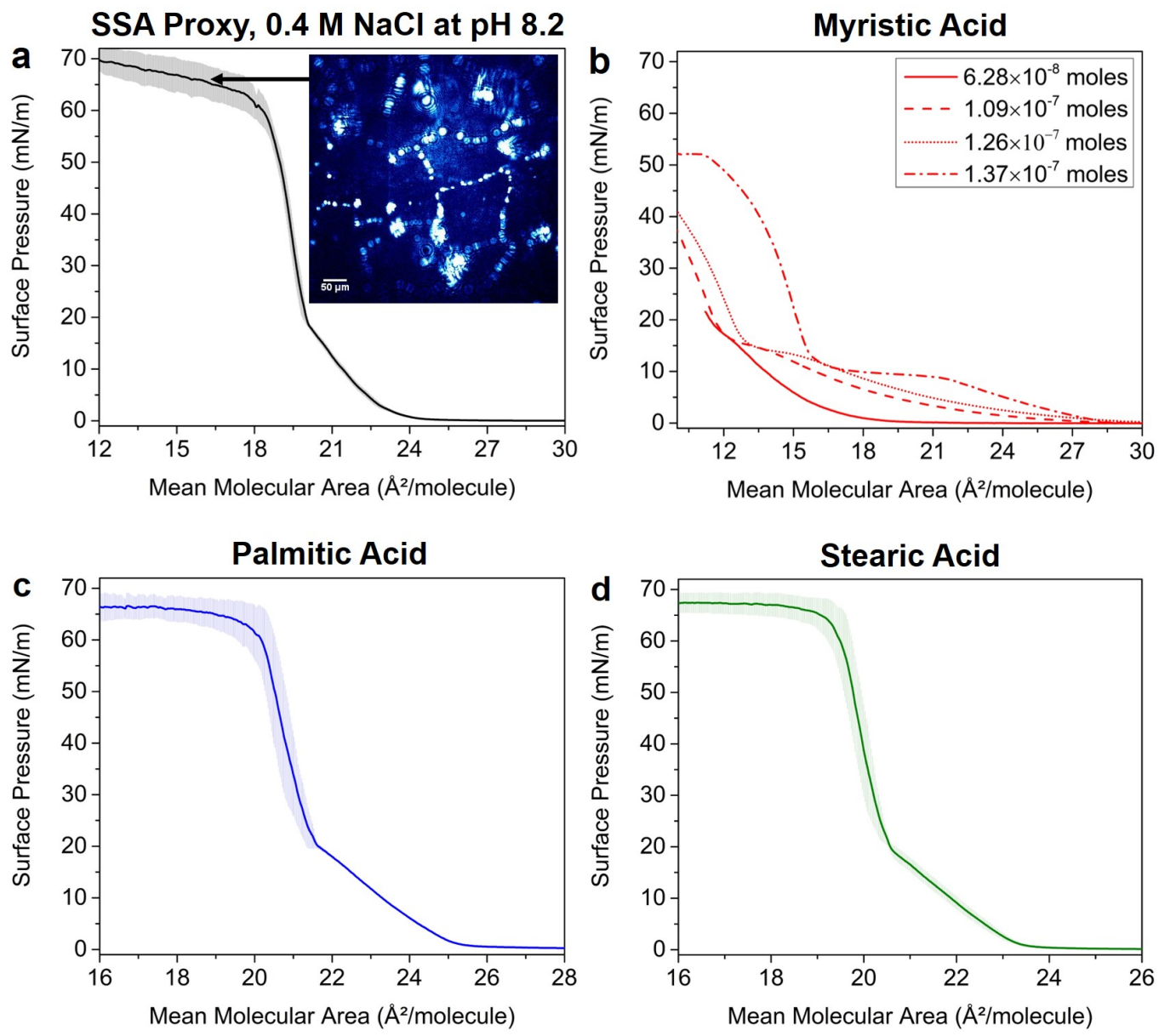

Figure 1. $\Pi-A$ isotherms of the sea spray aerosol (SSA) proxy film and its individual components at pH 8.2: (a) SSA proxy film and a Brewster angle microscope (BAM) image of the monolayer collapse; (b) myristic acid (MA) spread at different amounts at the air-water interface; (c) palmitic acid (PA); and (d) stearic acid (SA). The BAM image scale bar is $50 \mu \mathrm{m}$ (see Supplementary Materials).

The SSA proxy monolayer (Figure 1a) undergoes a 2D phase transition from a gas-tilted condensed (G-TC) coexistence phase to a tilted condensed (TC) phase at $24 \AA^{2} /$ molecule, known as the lift-off point $[66,94,95]$. Upon further compression in the TC phase, the monolayer transitions into the untilted condensed (UC) phase at a surface pressure of $18 \mathrm{mN} / \mathrm{m}$. The film reaches a maximum surface 
pressure around $70 \mathrm{mN} / \mathrm{m}$. The existence of only one collapse pressure $\left(\Pi_{c}\right)$ observed at $\sim 60 \mathrm{mN} / \mathrm{m}$ also suggests that the SSA proxy film is completely miscible. A monolayer containing immiscible components have different $\Pi_{c}$ points for each component, whereas miscible monolayers have a single $\Pi_{c}$ that is dependent upon the molar fraction of each component in the mixture [66,77]. Such a high $\Pi_{c}$ indicates that the SSA film on model seawater is resistant to collapse. This phase behavior could be caused in part by Coulombic repulsion between the negatively-charged carboxylate moieties and by contact ion pair formation between the carboxylate and $\mathrm{Na}^{+}$cation [96]. Alternatively, a surface pressure plateau could be the result of slow relaxation kinetics caused by strong cohesive forces between the lipids [70]. Further insight into the intermolecular interactions contributing to the surface pressure plateau can be obtained from the individual fatty acid isotherms.

MA (Figure 1b) is the shortest of the long chain fatty acids, yielding a smaller sum of dispersion interactions between the lipids. As a result, MA films at the air-water interface are more disordered and pack less tightly $[66,97,98]$. MA is partially soluble in water [71,72], and its rate of desorption increases with carboxylic acid headgroup deprotonation because of the strong electrostatic interactions between the carboxylate moiety and water molecules. MA is largely deprotonated at $\mathrm{pH} 8.2$ based on the surface $\mathrm{pK}_{a}$ value of 7.88 at $20{ }^{\circ} \mathrm{C}$ [75], so a stable monolayer could not be obtained for the model seawater subphase due to dissolution. Increasing the amount of fatty acid spread onto the air-water interface helped to overcome the diffusion-mediated desorption, but the mechanical forcing from lateral barrier compression during the $\Pi-A$ isotherm experiment promoted desorption. Hence, the monolayer was not stable, so collapse could not be reached.

Both PA (Figure 1c) and SA (Figure 1d) achieve a surface pressure plateau at collapse around $\sim 67 \mathrm{mN} / \mathrm{m}$ on $0.4 \mathrm{M} \mathrm{NaCl}$ at $\mathrm{pH}$ 8.2. PA and SA should be partially deprotonated on this model seawater subphase given their surface $\mathrm{pK}_{a}$ values of 8.34 at $20^{\circ} \mathrm{C}$ and 9.89 at $20^{\circ} \mathrm{C}$, respectively [75]. However, the lipids are largely insoluble because of the greater dispersion interactions between the alkyl chains which generates a more rigid film. The PA lift-off point was measured at $25.5 \AA^{2} /$ molecule, and SA lift-off occurred at $23.5 \AA^{2} /$ molecule. PA and SA underwent the tilted condensed-untilted condensed (TC-UC) phase transition at $\sim 20 \mathrm{mN} / \mathrm{m}$. PA and SA $\Pi-A$ isotherms are similar to the SSA proxy isotherm, suggesting that the mixture film dynamic behavior resembles that of the individual fatty acids. The SSA proxy lift-off point is intermediate between the PA and SA lift-off points, further supporting that the monolayer mixture is miscible. Miscible monolayers have phase transitions that are dependent upon the molar fraction of each component in the mixture; thus, the monolayer mixture lift-off occurs at a pressure between that of its individual components [66,77]. While PA and SA monolayers are good models of SSA film behavior on $0.4 \mathrm{M} \mathrm{NaCl}$ at pH 8.2, the SSA proxy monolayer has a different isotherm slope at collapse which could indicate small differences in the collapse mechanisms.

SSA film rigidity partially governs the monolayer collapse mechanism into 3D structures. Fluid monolayers lose material by desorption into the aqueous subphase and have low $\Pi_{c}$. Rigid or highly ordered monolayers tend to collapse by forming multilayer aggregates in the air phase or by desorption into the aqueous phase, and the $\Pi_{c}$ is often high. When the monolayer possesses intermediate rigidity, it can buckle and form protrusions into the subphase, known as a folding collapse. Defects in the monolayer act as folding nucleation sites, leading to random protrusions that coexist with the monolayer. Continuous compression after protrusion formation increases the fraction of monolayer in the folds relative to the flat regions such that a constant $\Pi_{c}$ is maintained. Monolayer folding is a reversible process unlike film desorption and fracturing, so the monolayer molecular organization is maintained throughout dynamic compression and expansion $[82,84,85,99,100]$. Changes in film morphology can affect SSA uptake of trace gases and water vapor in the MBL, so understanding SSA film collapse mechanisms is important for better predictions of SSA radiative effects and surface reactivity in climate models.

BAM was used to visualize the SSA proxy collapse structure that gives rise to the surface pressure plateau on $0.4 \mathrm{M} \mathrm{NaCl}$ at $\mathrm{pH} 8.2$ (Figure 1a). Small white spots approximately 5-10 $\mu \mathrm{m}$ in diameter 
appeared in the condensed phase at surface pressures below the $\Pi_{c}$ (image not shown). These spots are indicative of monolayer-bound vesicle budding [101]. At $\Pi_{c}$, bright white lines began to encompass many of the budding vesicles, and further compression caused the lines to become more interconnected. The presence of lines suggest a folding collapse mechanism in which the budding vesicles are likely incorporated into the folds [85,101-103]. A surface pressure plateau is also indicative of monolayer folding. Film material is incorporated into the folds with compression, and the surface pressure rises only minimally because molecular organization within the film itself does not change. Instead, the surface pressure slowly rises as new folding nuclei form upon compression [85]. This suggests that nascent SSA films are resistant to collapse into 3D structures and may be able to retain their molecular organization during dynamic compression. SSA particle shrinkage could then create an even greater aerosol surface-to-volume ratio due to film folding at the interface.

\subsection{Effects of SSA Proxy Aqueous Composition on the Film Phase Behavior}

In order to understand how SSA interfacial organization changes throughout SSA residence in the MBL, the $0.4 \mathrm{M} \mathrm{NaCl}$ aqueous subphase $\mathrm{pH}$ was lowered to 5.6 in the $\Pi-A$ isotherm and BAM experiments (Figure 2). The SSA proxy monolayer lift-off point (Figure 2a) occurs at $25 \AA^{2} /$ molecule, and the film undergoes the TC-UC phase transition at $\sim 18 \mathrm{mN} / \mathrm{m}$. A surface pressure plateau at collapse occurs at $\sim 64 \mathrm{mN} / \mathrm{m}$. The $\Pi_{c}$ on $0.4 \mathrm{M} \mathrm{NaCl}$ at pH 5.6 is slightly lower than the $\Pi_{c}$ at $\mathrm{pH} 8.2$ (Figure 1a), indicating that the monolayer begins to fold at a lower surface pressure at $\mathrm{pH}$ 5.6. BAM also suggests that part of the SSA proxy monolayer on $0.4 \mathrm{M} \mathrm{NaCl}$ at $\mathrm{pH} 5.6$ folds at collapse (inset in Figure 1a). Small 3D nuclei begin to form in the UC phase just before the $\Pi_{c}$, and some of these nuclei become connected by thin white lines upon further compression at collapse. Line structures are indicative of monolayer folding [85]. However, a significant number of these small 3D nuclei do not coalesce into line structures, and the number of 3D nuclei increases with compression. The lower collapse pressure at $\mathrm{pH} 5.6$ is likely caused by a fraction of more rigid film material being incorporated into vesicles that detach from the monolayer, meaning that less of the film is incorporated into folds [104]. Changes in the SSA proxy film organization and fluidity on subphases with differing $\mathrm{pH}$ suggest that aerosol particle $\mathrm{pH}$ is important in modulating SSA film dynamics in the MBL.

While the SSA proxy monolayer folds at collapse, its individual fatty acid components do not fold on the same subphase conditions. MA (Figure $2 b$ ) lifts off around $41 \AA^{2} /$ molecule and enters a TC-UC coexistence phase $[80,105,106]$ at $\sim 15 \mathrm{mN} / \mathrm{m}$. The monolayer exists in the UC phase at surface pressures higher than $15 \mathrm{mN} / \mathrm{m}$ until the $\Pi_{c}$ is reached at $\sim 48 \mathrm{mN} / \mathrm{m}$, and then the surface pressure drops with further compression. PA (Figure 2c) and SA (Figure 2d) isotherms also exhibit a similar collapse mechanism to MA with $\Pi_{c}$ values at $\sim 62 \mathrm{mN} / \mathrm{m}$ and $\sim 67 \mathrm{mN} / \mathrm{m}$, respectively, and their surface pressures decrease after collapse. The other PA and SA phase transitions remain relatively unchanged in comparison to the individual fatty acid isotherms on $0.4 \mathrm{M} \mathrm{NaCl}$ at $\mathrm{pH}$ 8.2. The lift-off point is increased by $1 \AA^{2} /$ molecule for both PA and SA at pH 5.6, and the TC-UC phase transition is increased by $\sim 2-3 \mathrm{mN} / \mathrm{m}$ for both fatty acids, suggesting that the monolayer is less fluid on salt water at $\mathrm{pH} 5.6$ than on model seawater. 
SSA Proxy, $0.4 \mathrm{M} \mathrm{NaCl}$ at $\mathrm{pH} 5.6$

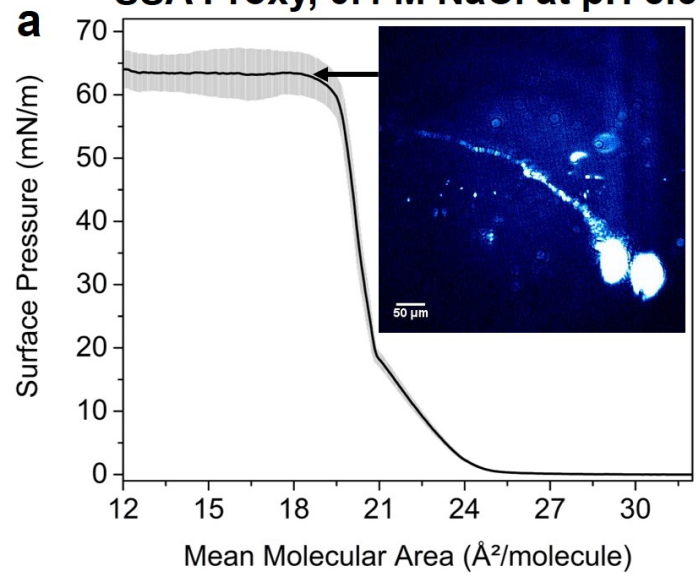

Palmitic Acid

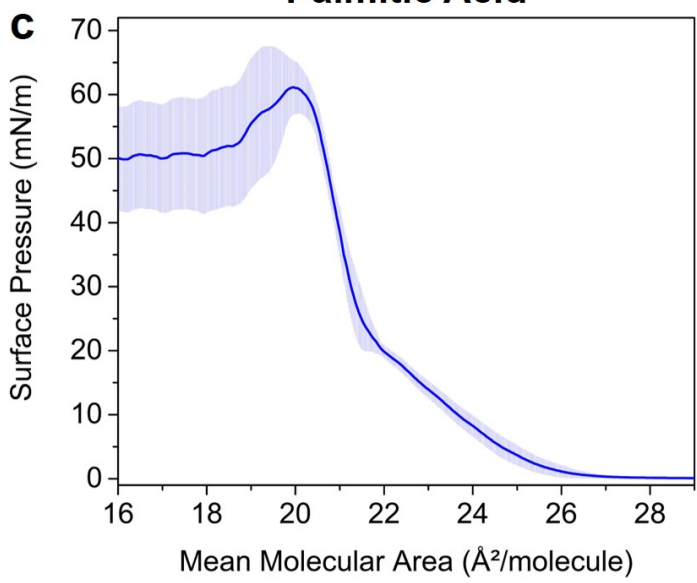

Myristic Acid

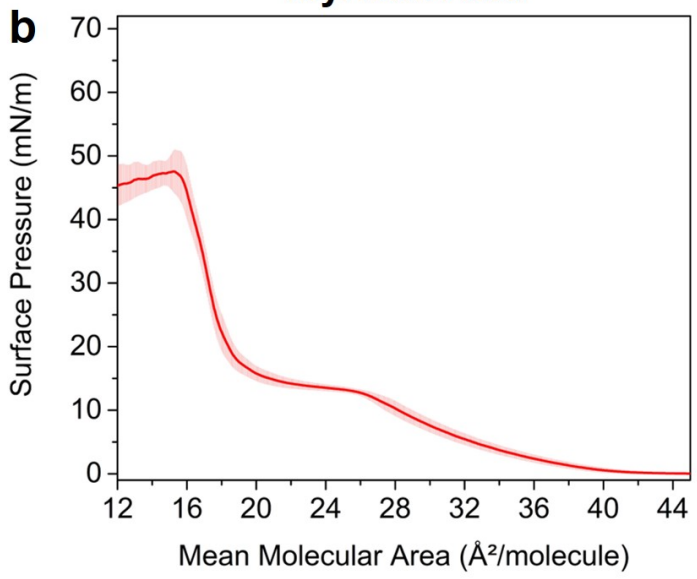

Stearic Acid

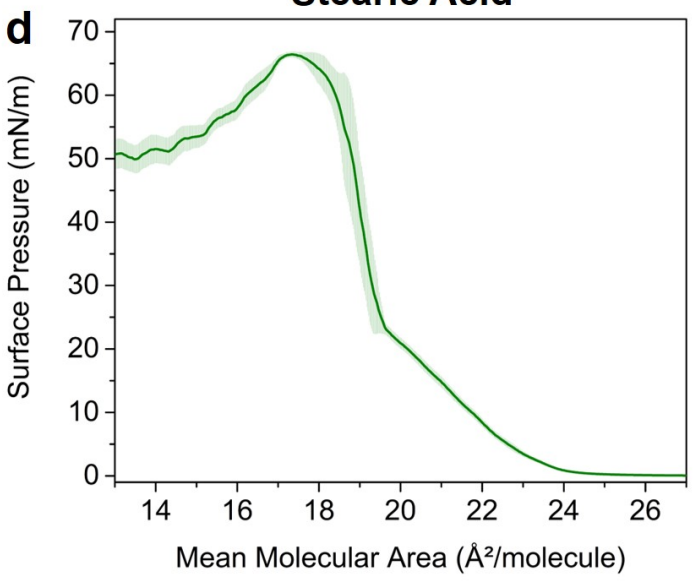

Figure 2. $\Pi-A$ isotherms of the SSA proxy film and its individual components at $\mathrm{pH}$ 5.6: (a) SSA proxy film and a BAM image of the monolayer collapse, (b) myristic acid (MA), (c) palmitic acid (PA), and (d) stearic acid (SA). The BAM image scale bar is $50 \mu \mathrm{m}$ (see Supplementary Materials).

Both the $\Pi-A$ isotherms and BAM images demonstrate significant differences between the SSA proxy film collapse on aqueous $\mathrm{NaCl}$ as compared to ultrapure water (Figure 3). A surface pressure plateau is observed at $\sim 64 \mathrm{mN} / \mathrm{m}$ on $0.4 \mathrm{M} \mathrm{NaCl}$, whereas the $\Pi_{c}$ on $\mathrm{H}_{2} \mathrm{O}$ is $\sim 53 \mathrm{mN} / \mathrm{m}$. Both line structures and 3D nuclei are observed in the BAM images on salt water, suggesting that $\mathrm{NaCl}$ introduces sufficient fluidity to promote a folding collapse mechanism. On water at $\mathrm{pH} 5.6$ (Figure 2 inset), the SSA proxy film initially forms small 3D nuclei at a surface pressure less than the $\Pi_{c}$. The 3D nuclei aggregate into larger, irregular structures upon reaching monolayer collapse. Both the formation of larger 3D aggregates and the decrease in surface pressure following further compression indicates that the SSA proxy monolayer on water fractionates upon reaching $\Pi_{c}$. Although the monolayer is partially deprotonated at $\mathrm{pH} 5.6$, the dispersion interactions between the alkyl chains are likely greater than the subphase-head group interactions. Consequently, the film is more rigid and readily breaks when the size and concentration of 3D nuclei becomes sufficiently large [70]. Thus, a folding collapse is likely water mediated and promoted by contact ion pair interactions between the carboxylate head group and $\mathrm{Na}^{+}$ion which fluidize the monolayer sufficiently $[96,107]$. At $\mathrm{pH} 5.6$, the head groups are still deprotonated such that these ion pairs form easily, but the partial protonation likely decreases the magnitude of these subphase-head group interactions which increases the rigidity of the film. 


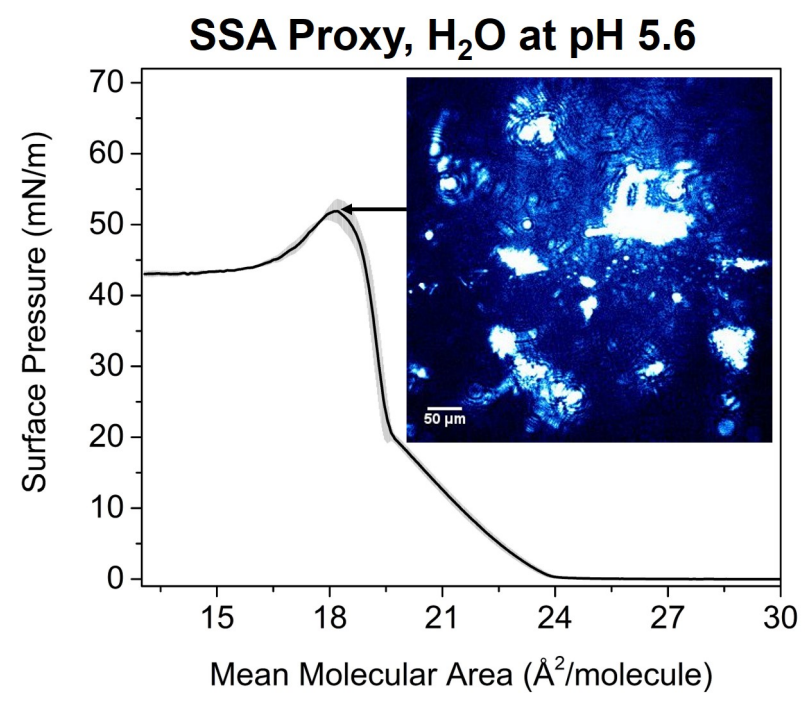

Figure 3. $\Pi-A$ isotherm of the SSA proxy film on $\mathrm{H}_{2} \mathrm{O}$ at $\mathrm{pH} 5.6$ and a $\mathrm{BAM}$ image of the monolayer collapse. The BAM image scale bar is $50 \mu \mathrm{m}$ (see Supplementary Materials).

\subsection{Aged SSA Proxy Film Phase Behavior}

When the SSA proxy film is completely protonated on $0.4 \mathrm{M} \mathrm{NaCl}$ at $\mathrm{pH} 2.0$, the $\Pi-A$ isotherm and BAM image indicate that the film no longer folds at collapse (Figure 4). The lift-off point is significantly higher at $28 \AA^{2} /$ molecule, caused by decreased MA solubility at low $\mathrm{pH}$. Like the other SSA proxy isotherms, the TC-UC phase transition occurs around $\sim 20 \mathrm{mN} / \mathrm{m}$. Upon monolayer collapse, the $\Pi-A$ isotherm reaches a $\Pi_{c}$ of $\sim 58 \mathrm{mN} / \mathrm{m}$ before the surface pressure decreases. BAM images reveal that the film forms 3D nuclei 5-10 $\mu \mathrm{m}$ in diameter and that the nuclei do not aggregate even beyond the $\Pi_{c}$. This collapse structure suggests that the monolayer is too rigid to fold due to weaker subphase-head group interactions, so the film collapses into 3D vesicles. Consequently, SSA acidification in the MBL is expected to induce significant changes in film organization, particularly during seasons of high biological productivity.

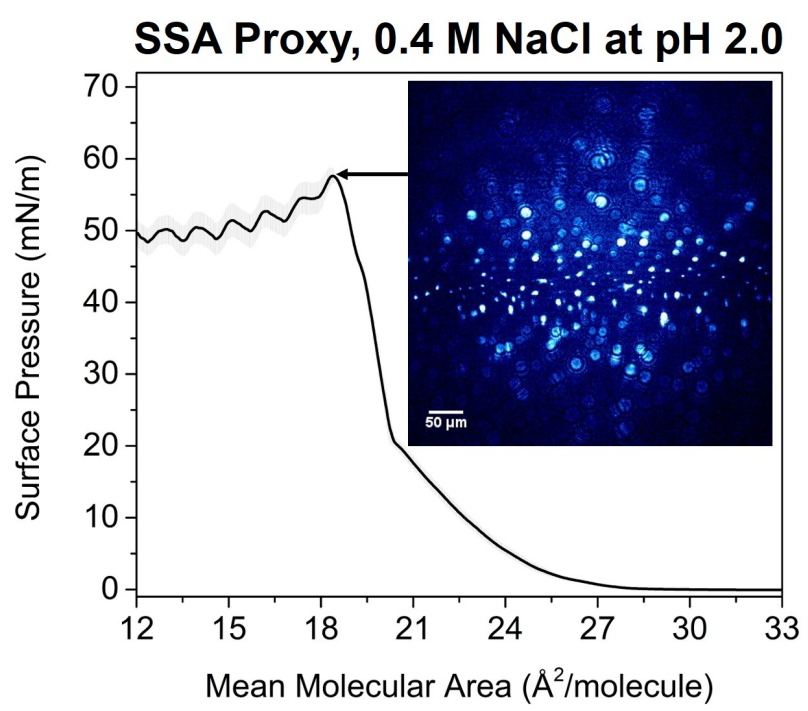

Figure 4. $\Pi-A$ isotherm of the SSA proxy film on $0.4 \mathrm{M} \mathrm{NaCl}$ at $\mathrm{pH} 2.0$ and a BAM image of the monolayer collapse. The BAM image scale bar is $50 \mu \mathrm{m}$ (see Supplementary Materials). 


\subsection{SSA Film Collapse Mechanisms and Their Atmospheric Implications}

A comparison of the collapse pressures for the SSA proxy mixture and its individual fatty acid components on various subphase conditions is plotted in Figure 5. Resistance to a 2D to 3D transformation increases with increasing $\mathrm{pH}$. The SSA proxy mixture on $0.4 \mathrm{M} \mathrm{NaCl}$ exhibits the highest $\Pi_{c}$ at $\mathrm{pH} 8.2$, and the $\Pi_{c}$ steadily decreases with subphase acidification. However, the $\Pi_{c}$ of the SSA proxy film on ultrapure water at $\mathrm{pH} 5.6$ is significantly lower than that of the film on salt water at the same $\mathrm{pH}$, indicating that both salt and $\mathrm{pH}$ are important in stabilizing the 2D monolayer at the air-water interface. Additionally, the strength of the dispersion interactions between the alkyl chains of the fatty acids are important in controlling film rigidity. MA exhibited the most fluid monolayer because of the weaker dispersion interactions, albeit the monolayer was unstable. SA was highly rigid as shown by the nearly identical collapse surface pressures at both $\mathrm{pH} 5.6$ and 8.2. PA and SA had collapse surface pressures close to that of the SSA proxy mixture, but the individual fatty acids alone were not able to completely reproduce the collapse behavior at all $\mathrm{pH}$ values. Therefore, while the lateral dispersion interactions are crucial in regulating film rigidity, the subphase-head group interactions modulated by $\mathrm{pH}$ and salt are the most important factors in determining the collapse mechanism for the SSA proxy film. Further studies are needed to evaluate how other marine-relevant salts and organic compounds impact the mechanical properties of the SSA proxy film.

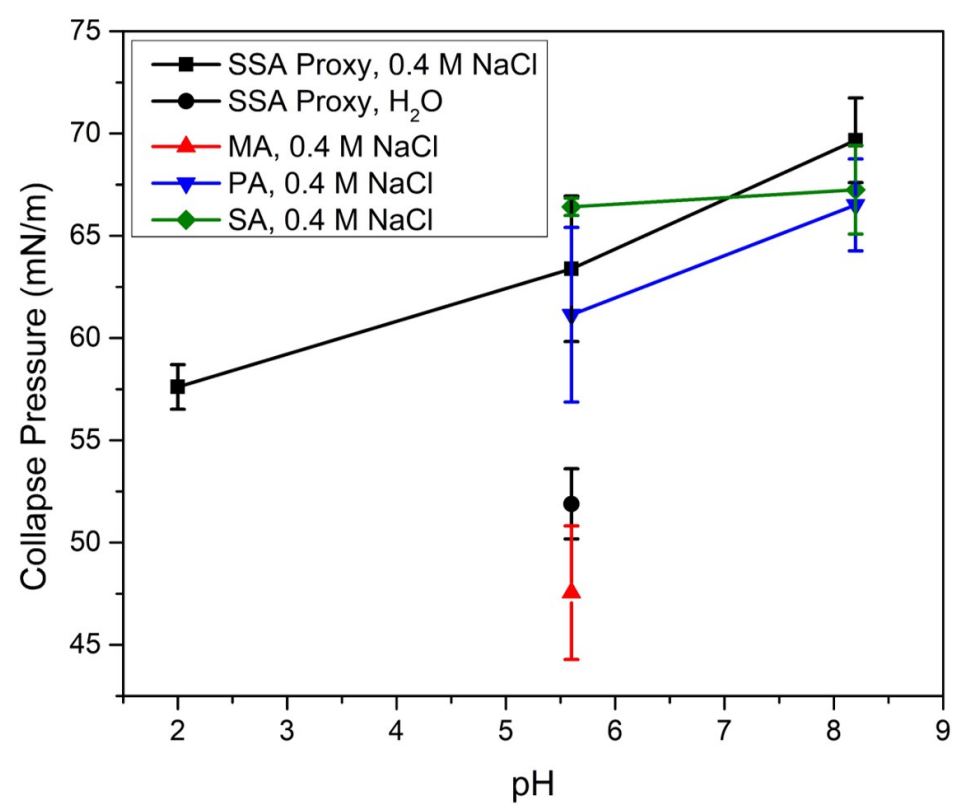

Figure 5. Collapse pressures of the SSA proxy film and its individual fatty acid components plotted as a function of subphase $\mathrm{pH}$ (see Supplementary Materials).

Probable film collapse mechanisms on SSA surfaces in the MBL are summarized in Figure 6. The organic coating of nascent SSA is likely to fold upon particle contraction during periods of high marine biological activity. As a result, nascent SSA is dynamic and retains its interfacial molecular organization. However, as the particle interacts with trace gases in the MBL and acidifies, the film becomes more rigid. Monolayer folding is still observed, but 3D nuclei also begin to form at the surface as the interfacial area is reduced. Folding ceases when the monolayer is fully protonated, and only the $3 \mathrm{D}$ nuclei are observed. This change in collapse indicates that the SSA film fractionates and undergoes significant reorganization at low $\mathrm{pH}$. Monolayers on acidic subphases, such as the films on aged SSA, are less dynamic and less resistant to 3D transformations, so some film material is removed from the surface when the available area is too small. It is therefore reasonable to assert that interfacial reactivity and the nucleation ability of SSA particles change as the interfacial molecular environment is altered via $\mathrm{pH}$ and salt concentration, thereby yielding different impacts on climate upon aerosol aging in the 
MBL. The studies described herein reveal interfacial morphological changes of complex SSA proxy systems as a function of $\mathrm{pH}$ to better understand SSA surfaces.

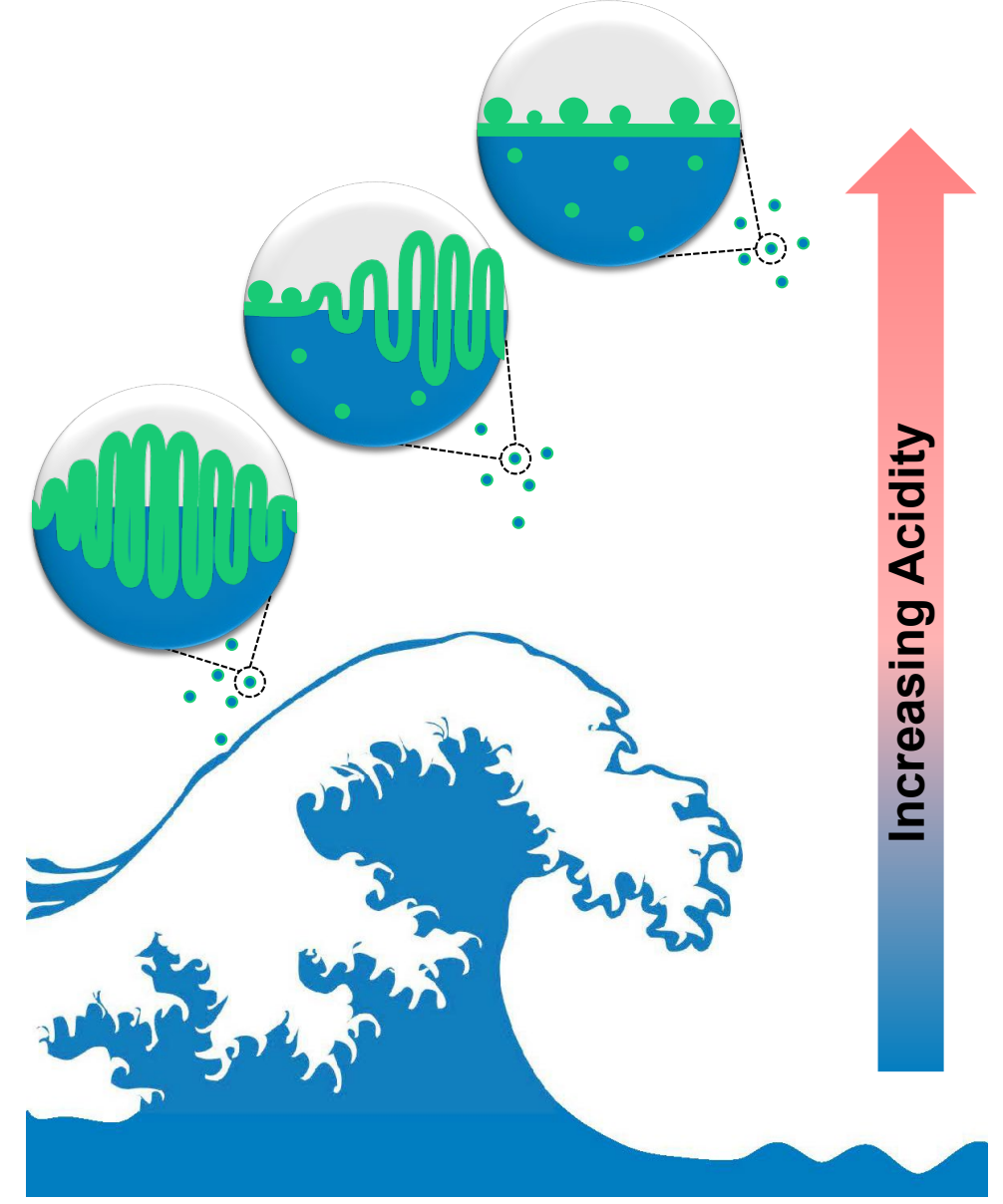

Figure 6. Illustration of the proposed SSA proxy film collapse mechanisms throughout particle residence in the marine boundary layer (MBL). Increased acidity is associated with longer aging in the MBL. The light gray circles correspond to zoomed-in schematics of the collapsed SSA proxy film. Nascent SSA films (bottom circle) fold at collapse. Upon subphase acidification (middle circle), the collapsed film folds and forms 3D nuclei simultaneously. After a significant amount of aging (top circle), the film no longer folds and only forms 3D nuclei at collapse (see Supplementary Materials).

Supplementary Materials: Data used to generate figures and conclusions in this manuscript are included in a Center for Aerosol Impacts on Chemistry of the Environment (CAICE) dataset hosted by the UCSD Library Digital Collections (DOI: https:/ / doi.org/10.6075/J0ZK5DWH).

Author Contributions: K.A.C.-F. collected and processed all data. K.A.C.-F. wrote the manuscript, and all authors edited the manuscript. H.C.A. acquired funding, conceived the experiment, and supervised the project.

Funding: This research was funded by the National Science Foundation through the Center for Aerosol Impacts on Chemistry of the Environment (CAICE) under Grant No. CHE-1801971.

Acknowledgments: The authors gratefully acknowledge Stephen Baumler and Bethany Wellen Rudd for helpful discussions. We also thank Jamie Schiffer and Abigail Dommer of Rommie Amaro's research group at the University of California, San Diego for initially motivating this work.

Conflicts of Interest: The authors declare no conflict of interest.

\section{References}

1. De Leeuw, G.; Andreas, E.L.; Anguelova, M.D.; Fairall, C.W.; Lewis, E.R.; O’Dowd, C.; Schulz, M.; Schwartz, S.E. Production Flux of Sea Spray Aerosol. Rev. Geophys. 2011, 49, RG2001. [CrossRef] 
2. Carslaw, K.S.; Lee, L.A.; Reddington, C.L.; Pringle, K.J.; Rap, A.; Forster, P.M.; Mann, G.W.; Spracklen, D.V.; Woodhouse, M.T.; Regayre, L.A.; et al. Large Contribution of Natural Aerosols to Uncertainty in Indirect Forcing. Nature 2013, 503, 67-71. [CrossRef] [PubMed]

3. Haywood, J.; Boucher, O. Estimates of the Direct and Indirect Radiative Forcing Due to Tropospheric Aerosols: A Review. Rev. Geophys. 2000, 38, 513-543. [CrossRef]

4. Alpert, P.A.; Aller, J.Y.; Knopf, D.A. Ice Nucleation from Aqueous $\mathrm{NaCl}$ Droplets with and without Marine Diatoms. Atmos. Chem. Phys. 2011, 11, 5539-5555. [CrossRef]

5. Knopf, D.A.; Alpert, P.A.; Wang, B.; Aller, J.Y. Stimulation of Ice Nucleation by Marine Diatoms. Nat. Geosci. 2011, 4, 88-90. [CrossRef]

6. Pummer, B.G.; Budke, C.; Augustin-Bauditz, S.; Niedermeier, D.; Felgitsch, L.; Kampf, C.J.; Huber, R.G.; Liedl, K.R.; Loerting, T.; Moschen, T.; et al. Ice Nucleation by Water-Soluble Macromolecules. Atmos. Chem. Phys. 2015, 15, 4077-4091. [CrossRef]

7. Wilson, T.W.; Ladino, L.A.; Alpert, P.A.; Breckels, M.N.; Brooks, I.M.; Browse, J.; Burrows, S.M.; Carslaw, K.S.; Huffman, J.A.; Judd, C.; Kilthau, W.P.; et al. A Marine Biogenic Source of Atmospheric Ice-Nucleating Particles. Nature 2015, 525, 234-238. [CrossRef] [PubMed]

8. DeMott, P.J.; Hill, T.C.J.; McCluskey, C.S.; Prather, K.A.; Collins, D.B.; Sullivan, R.C.; Ruppel, M.J.; Mason, R.H.; Irish, V.E.; Lee, T.; et al. Sea Spray Aerosol as a Unique Source of Ice Nucleating Particles. Proc. Natl. Acad. Sci. USA 2016, 113, 5797-5803. [CrossRef] [PubMed]

9. Ladino, L.A.; Yakobi-Hancock, J.D.; Kilthau, W.P.; Mason, R.H.; Si, M.; Li, J.; Miller, L.A.; Schiller, C.L.; Huffman, J.A.; Aller, J.Y.; et al. Addressing the Ice Nucleating Abilities of Marine Aerosol: A Combination of Deposition Mode Laboratory and Field Measurements. Atmos. Environ. 2016, 132, 1-10. [CrossRef]

10. McCluskey, C.S.; Hill, T.C.J.; Malfatti, F.; Sultana, C.M.; Lee, C.; Santander, M.V.; Beall, C.M.; Moore, K.A.; Cornwell, G.C.; Collins, D.B.; et al. A Dynamic Link between Ice Nucleating Particles Released in Nascent Sea Spray Aerosol and Oceanic Biological Activity during Two Mesocosm Experiments. J. Atmos. Sci. 2016, 74, 151-166. [CrossRef]

11. Chance, R.J.; Hamilton, J.F.; Carpenter, L.J.; Hackenberg, S.C.; Andrews, S.J.; Wilson, T.W. Water-Soluble Organic Composition of the Arctic Sea Surface Microlayer and Association with Ice Nucleation Ability. Environ. Sci. Technol. 2018, 52, 1817-1826. [CrossRef] [PubMed]

12. McCluskey, C.S.; Hill, T.C.J.; Sultana, C.M.; Laskina, O.; Trueblood, J.; Santander, M.V.; Beall, C.M.; Michaud, J.M.; Kreidenweis, S.M.; Prather, K.A.; et al. A Mesocosm Double Feature: Insights into the Chemical Make-up of Marine Ice Nucleating Particles. J. Atmos. Sci. 2018. [CrossRef]

13. Moore, M.J.; Furutani, H.; Roberts, G.C.; Moffet, R.C.; Gilles, M.K.; Palenik, B.; Prather, K.A. Effect of Organic Compounds on Cloud Condensation Nuclei (CCN) Activity of Sea Spray Aerosol Produced by Bubble Bursting. Atmos. Environ. 2011, 45, 7462-7469. [CrossRef]

14. Gantt, B.; Xu, J.; Meskhidze, N.; Zhang, Y.; Nenes, A.; Ghan, S.J.; Liu, X.; Easter, R.; Zaveri, R. Global Distribution and Climate Forcing of Marine Organic Aerosol-Part 2: Effects on Cloud Properties and Radiative Forcing. Atmos. Chem. Phys. 2012, 12, 6555-6563. [CrossRef]

15. Modini, R.L.; Frossard, A.A.; Ahlm, L.; Russell, L.M.; Corrigan, C.E.; Roberts, G.C.; Hawkins, L.N.; Schroder, J.C.; Bertram, A.K.; Zhao, R.; et al. Primary Marine Aerosol-Cloud Interactions off the Coast of California. J. Geophys. Res. Atmos. 2015, 120, 4282-4303. [CrossRef]

16. Collins, D.B.; Bertram, T.H.; Sultana, C.M.; Lee, C.; Axson, J.L.; Prather, K.A. Phytoplankton Blooms Weakly Influence the Cloud Forming Ability of Sea Spray Aerosol. Geophys. Res. Lett. 2016, 43, 2016GL069922. [CrossRef]

17. Quinn, P.K.; Coffman, D.J.; Johnson, J.E.; Upchurch, L.M.; Bates, T.S. Small Fraction of Marine Cloud Condensation Nuclei Made up of Sea Spray Aerosol. Nat. Geosci. 2017, 10, 674-679. [CrossRef]

18. Brooks, S.D.; Thornton, D.C. Marine Aerosols and Clouds. Annu. Rev. Mar. Sci. 2018, 10, 289-313. [CrossRef] [PubMed]

19. Forestieri, S.D.; Staudt, S.M.; Kuborn, T.M.; Faber, K.; Ruehl, C.R.; Bertram, T.H.; Cappa, C.D. Establishing the Impact of Model Surfactants on Cloud Condensation Nuclei Activity of Sea Spray Aerosol Mimics. Atmos. Chem. Phys. 2018, 18, 10985-11005. [CrossRef]

20. Gaston, C.; Cahill, J.; Collins, D.; Suski, K.; Ge, J.; Barkley, A.; Prather, K.; Gaston, C.J.; Cahill, J.F.; Collins, D.B.; et al. The Cloud Nucleating Properties and Mixing State of Marine Aerosols Sampled along the Southern California Coast. Atmosphere 2018, 9, 52. [CrossRef] 
21. Ault, A.P.; Guasco, T.L.; Baltrusaitis, J.; Ryder, O.S.; Trueblood, J.V.; Collins, D.B.; Ruppel, M.J.; Cuadra-Rodriguez, L.A.; Prather, K.A.; Grassian, V.H. Heterogeneous Reactivity of Nitric Acid with Nascent Sea Spray Aerosol: Large Differences Observed between and within Individual Particles. J. Phys. Chem. Lett. 2014, 5, 2493-2500. [CrossRef] [PubMed]

22. Estillore, A.D.; Trueblood, J.V.; Grassian, V.H. Atmospheric Chemistry of Bioaerosols: Heterogeneous and Multiphase Reactions with Atmospheric Oxidants and Other Trace Gases. Chem. Sci. 2016, 7, 6604-6616. [CrossRef] [PubMed]

23. Trueblood, J.V.; Estillore, A.D.; Lee, C.; Dowling, J.A.; Prather, K.A.; Grassian, V.H. Heterogeneous Chemistry of Lipopolysaccharides with Gas-Phase Nitric Acid: Reactive Sites and Reaction Pathways. J. Phys. Chem. A 2016, 120, 6444-6450. [CrossRef] [PubMed]

24. Shrestha, M.; Luo, M.; Li, Y.; Xiang, B.; Xiong, W.; Grassian, V.H. Let There Be Light: Stability of Palmitic Acid Monolayers at the Air/Salt Water Interface in the Presence and Absence of Simulated Solar Light and a Photosensitizer. Chem. Sci. 2018, 9, 5716-5723. [CrossRef] [PubMed]

25. Veghte, D.P.; Altaf, M.B.; Freedman, M.A. Size Dependence of the Structure of Organic Aerosol. J. Am. Chem. Soc. 2013, 135, 16046-16049. [CrossRef] [PubMed]

26. Altaf, M.B.; Zuend, A.; Freedman, M.A. Role of Nucleation Mechanism on the Size Dependent Morphology of Organic Aerosol. Chem. Commun. 2016, 52, 9220-9223. [CrossRef] [PubMed]

27. Losey, D.J.; Parker, R.G.; Freedman, M.A. pH Dependence of Liquid-Liquid Phase Separation in Organic Aerosol. J. Phys. Chem. Lett. 2016, 7, 3861-3865. [CrossRef] [PubMed]

28. Freedman, M.A. Phase Separation in Organic Aerosol. Chem. Soc. Rev. 2017, 46, 7694-7705. [CrossRef] [PubMed]

29. Altaf, M.B.; Dutcher, D.D.; Raymond, T.M.; Freedman, M.A. Effect of Particle Morphology on Cloud Condensation Nuclei Activity. ACS Earth Space Chem. 2018, 2, 634-639. [CrossRef]

30. Gavish, M.; Popovitz-Biro, R.; Lahav, M.; Leiserowitz, L. Ice Nucleation by Alcohols Arranged in Monolayers at the Surface of Water Drops. Science 1990, 250, 973-975. [CrossRef] [PubMed]

31. Ochshorn, E.; Cantrell, W. Towards Understanding Ice Nucleation by Long Chain Alcohols. J. Chem. Phys. 2006, 124, 054714. [CrossRef] [PubMed]

32. Knopf, D.A.; Forrester, S.M. Freezing of Water and Aqueous NaCl Droplets Coated by Organic Monolayers as a Function of Surfactant Properties and Water Activity. J. Phys. Chem. A 2011, 115, 5579-5591. [CrossRef] [PubMed]

33. Lupi, L.; Peters, B.; Molinero, V. Pre-Ordering of Interfacial Water in the Pathway of Heterogeneous Ice Nucleation Does Not Lead to a Two-Step Crystallization Mechanism. J. Chem. Phys. 2016, 145, 211910. [CrossRef] [PubMed]

34. Qiu, Y.; Odendahl, N.; Hudait, A.; Mason, R.; Bertram, A.K.; Paesani, F.; DeMott, P.J.; Molinero, V. Ice Nucleation Efficiency of Hydroxylated Organic Surfaces Is Controlled by Their Structural Fluctuations and Mismatch to Ice. J. Am. Chem. Soc. 2017, 139, 3052-3064. [CrossRef] [PubMed]

35. Takahama, S.; Liu, S.; Russell, L.M. Coatings and Clusters of Carboxylic Acids in Carbon-Containing Atmospheric Particles from Spectromicroscopy and Their Implications for Cloud-Nucleating and Optical Properties. J. Geophys. Res. 2010, 115. [CrossRef]

36. Estillore, A.D.; Morris, H.S.; Or, V.W.; Lee, H.D.; Alves, M.R.; Marciano, M.A.; Laskina, O.; Qin, Z.; Tivanski, A.V.; Grassian, V.H. Linking Hygroscopicity and the Surface Microstructure of Model Inorganic Salts, Simple and Complex Carbohydrates, and Authentic Sea Spray Aerosol Particles. Phys. Chem. Chem. Phys. 2017, 19, 21101-21111. [CrossRef] [PubMed]

37. Cochran, R.E.; Jayarathne, T.; Stone, E.A.; Grassian, V.H. Selectivity Across the Interface: A Test of Surface Activity in the Composition of Organic-Enriched Aerosols from Bubble Bursting. J. Phys. Chem. Lett. 2016, 7, 1692-1696. [CrossRef] [PubMed]

38. Burrows, S.M.; Ogunro, O.; Frossard, A.A.; Russell, L.M.; Rasch, P.J.; Elliott, S.M. A Physically Based Framework for Modeling the Organic Fractionation of Sea Spray Aerosol from Bubble Film Langmuir Equilibria. Atmos. Chem. Phys. 2014, 14, 13601-13629. [CrossRef]

39. Elliott, S.; Burrows, S.M.; Deal, C.; Liu, X.; Long, M.; Ogunro, O.; Russell, L.M.; Wingenter, O. Prospects for Simulating Macromolecular Surfactant Chemistry at the Ocean-Atmosphere Boundary. Environ. Res. Lett. 2014, 9, 064012. [CrossRef] 
40. Elliott, S.; Burrows, S.; Cameron-Smith, P.; Hoffman, F.; Hunke, E.; Jeffery, N.; Liu, Y.; Maltrud, M.; Menzo, Z.; Ogunro, O.; et al. Does Marine Surface Tension Have Global Biogeography? Addition for the OCEANFILMS Package. Atmosphere 2018, 9, 216. [CrossRef]

41. Yoon, Y.J.; Ceburnis, D.; Cavalli, F.; Jourdan, O.; Putaud, J.P.; Facchini, M.C.; Decesari, S.; Fuzzi, S.; Sellegri, K.; Jennings, S.G.; et al. Seasonal Characteristics of the Physicochemical Properties of North Atlantic Marine Atmospheric Aerosols. J. Geophys. Res. 2007, 112, D04206. [CrossRef]

42. O'Dowd, C.D.; de Leeuw, G. Marine Aerosol Production: A Review of the Current Knowledge. Philos. Trans. R. Soc. Lond. Math. Phys. Eng. Sci. 2007, 365, 1753-1774. [CrossRef] [PubMed]

43. Gantt, B.; Meskhidze, N.; Facchini, M.C.; Rinaldi, M.; Ceburnis, D.; O’Dowd, C.D. Wind Speed Dependent Size-Resolved Parameterization for the Organic Mass Fraction of Sea Spray Aerosol. Atmos. Chem. Phys. 2011, 11, 8777-8790. [CrossRef]

44. Quinn, P.K.; Collins, D.B.; Grassian, V.H.; Prather, K.A.; Bates, T.S. Chemistry and Related Properties of Freshly Emitted Sea Spray Aerosol. Chem. Rev. 2015, 115, 4383-4399. [CrossRef] [PubMed]

45. O’Dowd, C.D.; Facchini, M.C.; Cavalli, F.; Ceburnis, D.; Mircea, M.; Decesari, S.; Fuzzi, S.; Yoon, Y.J.; Putaud, J.P. Biogenically Driven Organic Contribution to Marine Aerosol. Nature 2004, 431, 676-680. [CrossRef] [PubMed]

46. Facchini, M.C.; Rinaldi, M.; Decesari, S.; Carbone, C.; Finessi, E.; Mircea, M.; Fuzzi, S.; Ceburnis, D.; Flanagan, R.; Nilsson, E.D.; et al. Primary Submicron Marine Aerosol Dominated by Insoluble Organic Colloids and Aggregates. Geophys. Res. Lett. 2008, 35, L17814. [CrossRef]

47. Sciare, J.; Favez, O.; Sarda-Estève, R.; Oikonomou, K.; Cachier, H.; Kazan, V. Long-Term Observations of Carbonaceous Aerosols in the Austral Ocean Atmosphere: Evidence of a Biogenic Marine Organic Source. J. Geophys. Res. 2009, 114. [CrossRef]

48. Gantt, B.; Meskhidze, N. The Physical and Chemical Characteristics of Marine Primary Organic Aerosol: A Review. Atmos. Chem. Phys. 2013, 13, 3979-3996. [CrossRef]

49. Prather, K.A.; Bertram, T.H.; Grassian, V.H.; Deane, G.B.; Stokes, M.D.; DeMott, P.J.; Aluwihare, L.I.; Palenik, B.P.; Azam, F.; Seinfeld, J.H.; et al. Bringing the Ocean into the Laboratory to Probe the Chemical Complexity of Sea Spray Aerosol. Proc. Natl. Acad. Sci. USA 2013, 110, 7550-7555. [CrossRef] [PubMed]

50. Lee, C.; Sultana, C.M.; Collins, D.B.; Santander, M.V.; Axson, J.L.; Malfatti, F.; Cornwell, G.C.; Grandquist, J.R.; Deane, G.B.; Stokes, M.D.; et al. Advancing Model Systems for Fundamental Laboratory Studies of Sea Spray Aerosol Using the Microbial Loop. J. Phys. Chem. A 2015, 119, 8860-8870. [CrossRef] [PubMed]

51. Wang, X.; Sultana, C.M.; Trueblood, J.; Hill, T.C.J.; Malfatti, F.; Lee, C.; Laskina, O.; Moore, K.A.; Beall, C.M.; McCluskey, C.S.; et al. Microbial Control of Sea Spray Aerosol Composition: A Tale of Two Blooms. ACS Cent. Sci. 2015, 1, 124-131. [CrossRef] [PubMed]

52. Cochran, R.E.; Laskina, O.; Trueblood, J.V.; Estillore, A.D.; Morris, H.S.; Jayarathne, T.; Sultana, C.M.; Lee, C.; Lin, P.; Laskin, J.; et al. Molecular Diversity of Sea Spray Aerosol Particles: Impact of Ocean Biology on Particle Composition and Hygroscopicity. Chem 2017, 2, 655-667. [CrossRef]

53. Pham, D.Q.; O’Brien, R.; Fraund, M.; Bonanno, D.; Laskina, O.; Beall, C.; Moore, K.A.; Forestieri, S.; Wang, X.; Lee, C.; et al. Biological Impacts on Carbon Speciation and Morphology of Sea Spray Aerosol. ACS Earth Space Chem. 2017, 1, 551-561. [CrossRef]

54. Cochran, R.E.; Laskina, O.; Jayarathne, T.; Laskin, A.; Laskin, J.; Lin, P.; Sultana, C.; Lee, C.; Moore, K.A.; Cappa, C.D.; Bertram, T.H.; et al. Analysis of Organic Anionic Surfactants in Fine and Coarse Fractions of Freshly Emitted Sea Spray Aerosol. Environ. Sci. Technol. 2016, 50, 2477-2486. [CrossRef] [PubMed]

55. Patterson, J.P.; Collins, D.B.; Michaud, J.M.; Axson, J.L.; Sultana, C.M.; Moser, T.; Dommer, A.C.; Conner, J.; Grassian, V.H.; Stokes, M.D.; et al. Sea Spray Aerosol Structure and Composition Using Cryogenic Transmission Electron Microscopy. ACS Cent. Sci. 2016, 2, 40-47. [CrossRef] [PubMed]

56. Aller, J.Y.; Radway, J.C.; Kilthau, W.P.; Bothe, D.W.; Wilson, T.W.; Vaillancourt, R.D.; Quinn, P.K.; Coffman, D.J.; Murray, B.J.; Knopf, D.A. Size-Resolved Characterization of the Polysaccharidic and Proteinaceous Components of Sea Spray Aerosol. Atmos. Environ. 2017, 154, 331-347. [CrossRef]

57. Bertram, T.H.; Cochran, R.E.; Grassian, V.H.; Stone, E.A. Sea Spray Aerosol Chemical Composition: Elemental and Molecular Mimics for Laboratory Studies of Heterogeneous and Multiphase Reactions. Chem. Soc. Rev. 2018, 47, 2374-2400. [CrossRef] [PubMed] 
58. Jayarathne, T.; Sultana, C.M.; Lee, C.; Malfatti, F.; Cox, J.L.; Pendergraft, M.A.; Moore, K.A.; Azam, F.; Tivanski, A.V.; Cappa, C.D.; et al. Enrichment of Saccharides and Divalent Cations in Sea Spray Aerosol During Two Phytoplankton Blooms. Environ. Sci. Technol. 2016, 50, 11511-11520. [CrossRef] [PubMed]

59. Collins, D.B.; Zhao, D.F.; Ruppel, M.J.; Laskina, O.; Grandquist, J.R.; Modini, R.L.; Stokes, M.D.; Russell, L.M.; Bertram, T.H.; Grassian, V.H.; et al. Direct Aerosol Chemical Composition Measurements to Evaluate the Physicochemical Differences between Controlled Sea Spray Aerosol Generation Schemes. Atmos. Meas. Tech. 2014, 7, 3667-3683. [CrossRef]

60. Frossard Amanda, A.; Russell Lynn, M.; Burrows Susannah, M.; Elliott Scott, M.; Bates Timothy, S.; Quinn Patricia, K. Sources and Composition of Submicron Organic Mass in Marine Aerosol Particles. J. Geophys. Res. Atmos. 2014, 119, 12977-13003. [CrossRef]

61. Wang, X.; Deane, G.B.; Moore, K.A.; Ryder, O.S.; Stokes, M.D.; Beall, C.M.; Collins, D.B.; Santander, M.V.; Burrows, S.M.; Sultana, C.M.; et al. The Role of Jet and Film Drops in Controlling the Mixing State of Submicron Sea Spray Aerosol Particles. Proc. Natl. Acad. Sci. USA 2017, 114, 6978-6983. [CrossRef] [PubMed]

62. Tervahattu, H.; Hartonen, K.; Kerminen, V.M.; Kupiainen, K.; Aarnio, P.; Koskentalo, T.; Tuck, A.F.; Vaida, V. New Evidence of an Organic Layer on Marine Aerosols. J. Geophys. Res. 2002, 107, AAC 1-1-AAC 1-8. [CrossRef]

63. Tervahattu, H.; Juhanoja, J.; Kupiainen, K. Identification of an Organic Coating on Marine Aerosol Particles by TOF-SIMS. J. Geophys. Res. 2002, 107, ACH 18-1. [CrossRef]

64. Donaldson, D.J.; Vaida, V. The Influence of Organic Films at the Air-Aqueous Boundary on Atmospheric Processes. Chem. Rev. 2006, 106, 1445-1461. [CrossRef] [PubMed]

65. Griffith, E.C.; Adams, E.M.; Allen, H.C.; Vaida, V. Hydrophobic Collapse of a Stearic Acid Film by Adsorbed L-Phenylalanine at the Air-Water Interface. J. Phys. Chem. B 2012, 116, 7849-7857. [CrossRef] [PubMed]

66. Gaines, G.L. Insoluble Monolayers at Liquid-Gas Interfaces; Interscience Publishers: New York, NY, USA, 1966.

67. Joos, P. Effect of the $\mathrm{pH}$ on the Collapse Pressure of Fatty Acid Monolayers Evaluation of the Surface Dissociation Constant. Bull. SociÉtÉs Chim. Belg. 1971, 80, 277-281. [CrossRef]

68. Pezron, E.; Claesson, P.M.; Berg, J.M.; Vollhardt, D. Stability of Arachidic Acid Monolayers on Aqueous Salt Solutions. J. Colloid Interface Sci. 1990, 138, 245-254. [CrossRef]

69. Angelova, A.; Reiche, J.; Ionov, R.; Janietz, D.; Brehmer, L. Control of the Structure of Langmuir-Blodgett Films of a Discotic Liquid Crystalline Compound via the Subphase Composition and the Adjacent Molecular Environment. Thin Solid Film. 1994, 242, 289-294. [CrossRef]

70. Angelova, A.; Vollhardt, D.; Ionov, R. 2D-3D Transformations of Amphiphilic Monolayers Influenced by Intermolecular Interactions: A Brewster Angle Microscopy Study. J. Phys. Chem. 1996, 100, 10710-10720. [CrossRef]

71. Minassian-Saraga, L.T. Recent Work on Spread Monolayers, Adsorption and Desorption. J. Colloid Sci. 1956, 11, 398-418. [CrossRef]

72. Patil, G.S.; Matthews, R.H.; Cornwell, D.G. Kinetics of the Processes of Desorption from Fatty Acid Monolayers. J. Lipid Res. 1973, 14, 26-31. [PubMed]

73. Gershfeld, N.L. Physical Chemistry of Lipid Films at Fluid Interfaces. Annu. Rev. Phys. Chem. 1976, 27, 349-368. [CrossRef]

74. Gilman, J.; Eliason, T.; Fast, A.; Vaida, V. Selectivity and Stability of Organic Films at the Air-Aqueous Interface. J. Colloid Interface Sci. 2004, 280, 234-243. [CrossRef] [PubMed]

75. McLean, D.S.; Vercoe, D.; Stack, K.R.; Richardson, D. The Colloidal pKa of Lipophilic Extractives Commonly Found in Pinus Radiata. Appita J. J. Tech. Assoc. Aust. N. Z. Pulp Pap. Ind. 2005, 58, 362.

76. Wellen, B.A.; Lach, E.A.; Allen, H.C. Surface pKa of Octanoic, Nonanoic, and Decanoic Fatty Acids at the Air-Water Interface: Applications to Atmospheric Aerosol Chemistry. Phys. Chem. Chem. Phys. 2017, 39, 26551-26558. [CrossRef] [PubMed]

77. Dynarowicz-Łatka, P.; Kita, K. Molecular Interaction in Mixed Monolayers at the Air/Water Interface. Adv. Colloid Interface Sci. 1999, 79, 1-17. [CrossRef]

78. Rodrıǵuez Patino, J.M.; Rodrıǵuez Niño, M. Interfacial Characteristics of Food Emulsifiers (Proteins and Lipids) at the Air-Water Interface. Colloids Surf. B Biointerfaces 1999, 15, 235-252. [CrossRef]

79. Brzozowska, A.M.; Mugele, F.; Duits, M.H.G. Stability and Interactions in Mixed Monolayers of Fatty Acid Derivatives on Artificial Sea Water. Colloids Surf. A Physicochem. Eng. Asp. 2013, 433, 200-211. [CrossRef] 
80. Khattari, Z.; Sayyed, M.I.; Qashou, S.I.; Fasfous, I.; Al-Abdullah, T.; Maghrabi, M. Interfacial Behavior of Myristic Acid in Mixtures with DMPC and Cholesterol. Chem. Phys. 2017, 490, 106-114. [CrossRef]

81. McFate, C.; Ward, D.; Olmsted, J. Organized Collapse of Fatty Acid Monolayers. Langmuir 1993, 9, $1036-1039$. [CrossRef]

82. Ybert, C.; Lu, W.; Möller, G.; Knobler, C.M. Collapse of a Monolayer by Three Mechanisms. J. Phys. Chem. B 2002, 106, 2004-2008. [CrossRef]

83. Kundu, S.; Datta, A.; Hazra, S. Effect of Metal Ions on Monolayer Collapses. Langmuir 2005, 21, 5894-5900. [CrossRef] [PubMed]

84. Baoukina, S.; Monticelli, L.; Risselada, H.J.; Marrink, S.J.; Tieleman, D.P. The Molecular Mechanism of Lipid Monolayer Collapse. Proc. Natl. Acad. Sci. USA 2008, 105, 10803-10808. [CrossRef] [PubMed]

85. Lee, K.Y.C. Collapse Mechanisms of Langmuir Monolayers. Annu. Rev. Phys. Chem. 2008, 59, 771-791. [CrossRef] [PubMed]

86. Millero, F.J. Chemical Oceanography, 4th ed.; Taylor \& Francis: Boca Raton, FL, USA, 2013.

87. Fridlind, A.M.; Jacobson, M.Z. A Study of Gas-Aerosol Equilibrium and Aerosol pH in the Remote Marine Boundary Layer during the First Aerosol Characterization Experiment (ACE 1). J. Geophys. Res. Atmos. 2000, 105, 17325-17340. [CrossRef]

88. Huang, Z.; Hua, W.; Verreault, D.; Allen, H.C. Influence of Salt Purity on $\mathrm{Na}^{+}$and Palmitic Acid Interactions. J. Phys. Chem. A 2013, 117, 13412-13418. [CrossRef] [PubMed]

89. Adams, E.M.; Allen, H.C. Palmitic Acid on Salt Subphases and in Mixed Monolayers of Cerebrosides: Application to Atmospheric Aerosol Chemistry. Atmosphere 2013, 4, 315-336. [CrossRef]

90. Neal, J.F.; Zhao, W.; Grooms, A.J.; Flood, A.H.; Allen, H.C. Arginine-Phosphate Recognition Enhanced in Phospholipid Monolayers at Aqueous Interfaces. J. Phys. Chem. C 2018. [CrossRef]

91. Schneider, C.A.; Rasband, W.S.; Eliceiri, K.W. NIH Image to ImageJ: 25 Years of Image Analysis. Nat. Methods 2012, 9, 671-675. [CrossRef] [PubMed]

92. Millero, F.J.; Feistel, R.; Wright, D.G.; McDougall, T.J. The Composition of Standard Seawater and the Definition of the Reference-Composition Salinity Scale. Deep Sea Res. Part Oceanogr. Res. Pap. 2008, 55, 50-72. [CrossRef]

93. Durbin, M.K.; Shih, M.C.; Malik, A.; Zschack, P.; Dutta, P. Isotherm and X-ray Diffraction Studies of Mixed Monolayers. Colloids Surf. A Physicochem. Eng. Asp. 1995, 102, 173-179. [CrossRef]

94. Nutting, G.C.; Harkins, W.D. Pressure-Area Relations of Fatty Acid and Alcohol Monolayers. J. Am. Chem. Soc. 1939, 61, 1180-1187. [CrossRef]

95. Fischer, A.; Sackmann, E. Electron Microscopy and Electron Diffraction Study of Coexisting Phases of Pure and Mixed Monolayers Transferred onto Solid Substrates. J. Colloid Interface Sci. 1986, 112, 1-14. [CrossRef]

96. Adams, E.M.; Wellen, B.A.; Thiraux, R.; Reddy, S.K.; Vidalis, A.S.; Paesani, F.; Allen, H.C. Sodium-Carboxylate Contact Ion Pair Formation Induces Stabilization of Palmitic Acid Monolayers at High pH. Phys. Chem. Chem. Phys. 2017, 19, 10481-10490. [CrossRef] [PubMed]

97. Guyot-Sionnest, P.; Hunt, J.H.; Shen, Y.R. Sum-Frequency Vibrational Spectroscopy of a Langmuir Film: Study of Molecular Orientation of a Two-Dimensional System. Phys. Rev. Lett. 1987, 59, 1597-1600. [CrossRef] [PubMed]

98. Gericke, A.; Huehnerfuss, H. In Situ Investigation of Saturated Long-Chain Fatty Acids at the Air/Water Interface by External Infrared Reflection-Absorption Spectrometry. J. Phys. Chem. 1993, 97, 12899-12908. [CrossRef]

99. Smith, R.D.; Berg, J.C. The Collapse of Surfactant Monolayers at the Air-Water Interface. J. Colloid Interface Sci. 1980, 74, 273-286. [CrossRef]

100. Baoukina, S.; Rozmanov, D.; Mendez-Villuendas, E.; Tieleman, D.P. The Mechanism of Collapse of Heterogeneous Lipid Monolayers. Biophys. J. 2014, 107, 1136-1145. [CrossRef] [PubMed]

101. Gopal, A.; Lee, K.Y.C. Morphology and Collapse Transitions in Binary Phospholipid Monolayers. J. Phys. Chem. B 2001, 105, 10348-10354. [CrossRef]

102. Ding, J.; Takamoto, D.Y.; von Nahmen, A.; Lipp, M.M.; Lee, K.Y.C.; Waring, A.J.; Zasadzinski, J.A. Effects of Lung Surfactant Proteins, SP-B and SP-C, and Palmitic Acid on Monolayer Stability. Biophys. J. 2001, 80, 2262-2272. [CrossRef]

103. Takamoto, D.Y.; Lipp, M.M.; von Nahmen, A.; Lee, K.Y.C.; Waring, A.J.; Zasadzinski, J.A. Interaction of Lung Surfactant Proteins with Anionic Phospholipids. Biophys. J. 2001, 81, 153-169. [CrossRef] 
104. Ridsdale, R.; Palaniyar, N.; Possmayer, F.; Harauz, G. Formation of Folds and Vesicles by Dipalmitoylphosphatidylcholine Monolayers Spread in Excess. J. Membr. Biol. 2001, 180, 21-32. [CrossRef] [PubMed]

105. Pallas, N.R.; Pethica, B.A. Liquid-Expanded to Liquid-Condensed Transition in Lipid Monolayers at the Air/Water Interface. Langmuir 1985, 1, 509-513. [CrossRef]

106. Ruckenstein, E. On the Nature of The Liquid Expanded/Liquid Condensed Phase Transition in Monolayers of Polar Molecules. J. Colloid Interface Sci. 1997, 196, 313-315. [CrossRef] [PubMed]

107. Tang, C.Y.; Allen, H.C. Ionic Binding of $\mathrm{Na}^{+}$versus $\mathrm{K}^{+}$to the Carboxylic Acid Headgroup of Palmitic Acid Monolayers Studied by Vibrational Sum Frequency Generation Spectroscopy. J. Phys. Chem. A 2009, 113, 7383-7393. [CrossRef] [PubMed]

(C) 2018 by the authors. Licensee MDPI, Basel, Switzerland. This article is an open access article distributed under the terms and conditions of the Creative Commons Attribution (CC BY) license (http:/ / creativecommons.org/licenses/by/4.0/). 